\title{
System Dynamics Simulation Model to Increase Paddy Production for Food Security
}

\author{
Mala Rosa Aprillya ${ }^{1)^{*}}$, Erma Suryani ${ }^{2}$, Anisa Dzulkarnain ${ }^{3)}$ \\ 1)2)3) Institut Teknologi Sepuluh Nopember, Indonesia \\ Kampus ITS Keputih, Sukolilo, Surabaya 60111 \\ ${ }^{1)}$ rosaprillya@gmail.com, ${ }^{3)}$ anisadz225@gmail.com, ${ }^{2)}$ erma.suryani@gmail.com
}

Article history:

Received 3 February 2019

Revised 2 April 2019

Accepted 4 April 2019

Available online 28 April 2019

Keywords:

Food Security

Good Agricultural Practice

Paddy Production

System Dynamics

\begin{abstract}
Background: Food security is a world problem that often affects developing countries, one of them in Indonesia. Along with the increasing population growth population in Indonesia, this will affect the level of demand for rice for food needs. The problem of rice consumption and its fulfillment is an important agenda. If Indonesia does not want to depend on rice imports, then paddy production must continue to be increased. Therefore, food availability in each region is maintained to realize food security.

Objective: The purpose of this study is to analyze the factors that influence the increase paddy production in terms of cultivation and postharvest using a system dynamics model approach as the basis for policy strategy preparation.

Methods: System Dynamics (SD) approach with the consideration that this framework offers the ability to study and manage complex feedback systems and the ability to model non-linear behavior. Then do a series of decision scenarios to get the best results using computer assistance.

Results: Scenario results indicate that increasing paddy production to meet demand in Indonesia can be done by increasing the adoption of postharvest harvesting mechanisms coupled with the application of appropriate GAP (Good Agricultural Practice). It will increase paddy production in East Java so that it will make a large contribution to rice production in East Java.

Conclusion: This research can be used to improve paddy production to food security by improving harvesting mechanisms. For further research, we can consider increasing rendement paddy in supporting increased rice production.
\end{abstract}

\section{INTRODUCTION}

The food security system is a very critical and sensitive problem. Food security is a world problem that has attracted the attention of the Government and the scientific community. This mainly affects developing countries [1]. The problem of food security has become a national concern as a result of the scarcity of plants traditionally consumed as a staple food in several regions in Indonesia, as a result of post-crisis macroeconomic problems [2]. For Indonesia, rice concerns the interests of the wider community which in the effort to fulfill their needs must be handled seriously by the government. The agricultural sector must continue to be developed in order to remain a strength in determining food security, driving economic growth and a healthy economy [3].

Regional food security systems are influenced by interacting factors, such as climate change, population growth, excessive use of resources, changes in modes of consumption, governance failures and problems in the allocation and distribution of resources right under pressure and uncertainty which increasingly increase [4]. Land use problems, environmental consequences, and social acceptance also affect the food security system [5]. In terms of rice production, until now Java still has an important role, although some regions such as Sumatra, Sulawesi, and Kalimantan are also areas of rice production. However, the level of production produced by these regions is not as high as that produced by Java. In general, rice production is very dependent on land productivity which is influenced by several factors such as harvest area, rainfall, and fertilizer subsidies. Fulfillment of food sufficiency related to the provision of national rice which is a fairly complex system problem involving various components, elements or elements within it which are mutually integrated [6]. Food

\footnotetext{
${ }^{*}$ Corresponding author
} 
and agriculture systems have diverse multifunctional issues that involve a number of diverse stakeholders, with successful implementation of policy initiatives that require extensive knowledge and expertise [7]. Effective policy development that addresses food security will require a decision support tool and communication tool that allows planners and participants to understand and jointly develop strategies. In addition, the strategy needs to consider short and long-term impacts, as well as feedback that exists between several social, cultural, environmental, spatial, and financial phenomena [8]. All types of contextual factors can be modeled through a system dynamics (SD) model.

Dynamic systems are dynamic models that map flows, processes, and relationships between stakeholders contained in complex [9]. In a dynamic system, there is feedback which is the means by which changes in one part of the system affect another part of it and, consequently, the impact of a shocked component over time [10]. The feedback loop shows "closed chains and causes and effects that create feedback" [11]. There are two types of feedback loops in the SD model, namely the reinforcing (R) and balancing feedback loop (B). Strengthening or positive feedback loop reinforces behavior that occurs in a system [9]. The field of System Dynamics (SD) provides learning facilities about complex systems through the use of system diagrams and computer simulation models [9], also in the context of agricultural production and development. According to Diana [1] the using of dynamic system model in the decision-making process is helpful to predict future threats, to reduce food scarcity, and to deal with mismanagement of food resources. Wibowo's research [11] analyzed the impact of rice supply policy in the perspective of affordability and availability of rice stocks using a dynamic system model. System dynamic models are ways that can be used to represent the relationship between agriculture, food system drivers and their consequences for food security, the environment, and livelihoods; to represent quantified results through several regional scenarios, and to show how policies and technical interventions can be implemented into the system to get the best agricultural management decisions [12] [13] [14].

Therefore, in this study, we used the System Dynamics (SD) Framework to improve the quality of rice yields in supporting food security efforts. This study also aimed to improve previous research by including several additional conditions such as adoption of postharvest technology and the application of GAP. The results of the scenario model can be used as a tool for the government and stakeholders in developing decision-making strategies related to efforts to ensure food security. This paper is organized as follows. Part 1 explains the background. Part 2 explains the method. Section 3 presents the results. Section 4 presents the discussion. And finally, section 5 presents the research conclusions.

\section{METHODS}

System dynamics is a simulation methodology introduced by Jay Forrester to understand, visualize and analyze complex dynamic feedback systems. System Dynamics is a unique method that use to help managers and decision makers in order to find the policies and decisions that benefit and could be implemented well in a certain period of time [15]. This research consists of 4 steps: data collection, analysis of existing condition, identification significant variable, design of computer model: Causal Loop Diagram (CLD) and base model development and perform the process simulation with scenarios development.

\section{A. Data Collection}

The data used in this study as a reference for the development of the current national rice conditions such as paddy land area (ha), paddy production (ton), paddy productivity (ton / ha) and related to rice plants obtained from the Badan Pusat Statistic (BPS) East Java, Agriculture Office of East Java, and other related institutions, both in printed publications and websites. Paddy Land area data in East Java according to Badan Pusat Statistik [16] in 2007-2017 shown in Table 1.

TABLE 1

PADDY LAND AREA

\begin{tabular}{cc}
\hline Year & Paddy Land Area \\
\hline \hline 2007 & 1.096 .605 \\
2008 & 1.108 .578 \\
2009 & 1.100 .517 \\
2010 & 1.107 .276 \\
2011 & 1.106 .449 \\
2012 & 1.105 .550 \\
2013 & 1.102 .921 \\
2014 & 1.101 .765 \\
2015 & 1.091 .752 \\
2016 & 1.089 .834 \\
2017 & 1.087 .919 \\
\hline
\end{tabular}

Paddy productivity data in East Java according to Badan Pusat Statistik [17] in 2007-2017 shown in Table 2. 
TABLE 2

PADDY PRODUCTIVITY

\begin{tabular}{cc}
\hline \hline Year & Paddy Productivity \\
\hline 2007 & 5.41 \\
2008 & 5.90 \\
2009 & 5.91 \\
2010 & 5.9 \\
2011 & 5.50 \\
2012 & 6.17 \\
2013 & 5.91 \\
2014 & 5.98 \\
2015 & 6.11 \\
2016 & 5.9 \\
2017 & 5.72 \\
\hline
\end{tabular}

Paddy production in East Java according to Agriculture Office [18] in 2007-2017 shown in Table 3.

TABLE 3

PADDY PRODUCTION

\begin{tabular}{lc}
\hline \hline Year & Paddy Production \\
\hline 2007 & 10.836 .021 \\
2008 & 10.474 .773 \\
2009 & 11.259 .085 \\
2010 & 11.643 .773 \\
2011 & 10.576 .543 \\
2012 & 12.198 .707 \\
2013 & 12.049 .342 \\
2014 & 12.397 .049 \\
2015 & 13.154 .967 \\
2016 & 13.633 .701 \\
2017 & 13.125 .414 \\
\hline
\end{tabular}

Other secondary data are research related to the application of dynamic systems. These data will later be used as references in making models for research. Some of the literature that supports this research is taken from related sources, such as those contained in textbooks, experts, articles in relevant journals or previous studies that discuss the theory of the approach used in research as well as the conditions of production paddy to support food security, especially in the East Java province.

\section{B. Analysis Existing Conditions}

In Asia rice contributes 35\% energy and 28\% protein, $12 \%$ in South America and 9\% protein [19]. Rice (Oryza Sativa) is an important food crop in Indonesia. Rice production will continue to increase in line with the increasing rate of human birth. [20]. Improper harvest and post-harvest handling processes can cause a decrease in paddy production and quality. The production, post-harvest, milling, and marketing processes affect the quality of rice. [21]. Improper harvesting and postharvest processing are detrimental to farmers. In addition to post-harvest losses that cause low yields, it also causes low quality of paddy or rice produced. [22].

\section{Identification Significant Variable}

Modeler must understand of the system to develop good model. Understanding the system is needed in order to provide an overview of the interactions between components in a model. In this research, there are several model components (sub-models), namely: paddy land area, paddy productivity, and paddy p roduction in East Java. Sub model paddy land area consist of significant variable such as conversion and expansion land area. Sub model paddy productivity consist of significant variable such as harvest area [2], seed varieties [23], fertilizer [24][25], irrigation availability [26], and pest attack [27][28]. Sub model paddy production consist of variable harvest area [2], harvesting tool [29] [30], threshing tool [31] [32], pady drying [31][32] and post-harvest losses [33] [20].

\section{Design of Computer Model}

To develop a system dynamics models, some steps are required as follows Sterman [9]. The first stage is understanding the system to provide problem articulation. The second stage is formulating of dynamics hypothesis. The third stage is formulation of a simulation model. The four stage is testing of simulation model. Then, the last stage is policy design and evaluation. Formulation of simulation model system. Causal Loop Diagrams are developed to describe the interactions and relationships of the main variables in the model. The causal relationship in the model can be positive and negative. In the sub-model of paddy land area, positive link occurs when there was new expansion land as an area of paddy land area, it would increase the amount of paddy land area availability (R). Negative link occurs when land conversion in paddy areas continues, it would affect the amount of paddy land area availability (B). In the sub model paddy productivity positive link occurs when 
the seed varieties used were superior seeds, irrigation networks, fertilization is done correctly will help increase paddy productivity. Negative link occurs when there were amounts of pests that damage crops and reduce paddy productivity. Fig.1 shows the causal loop diagram of relationship in paddy production.

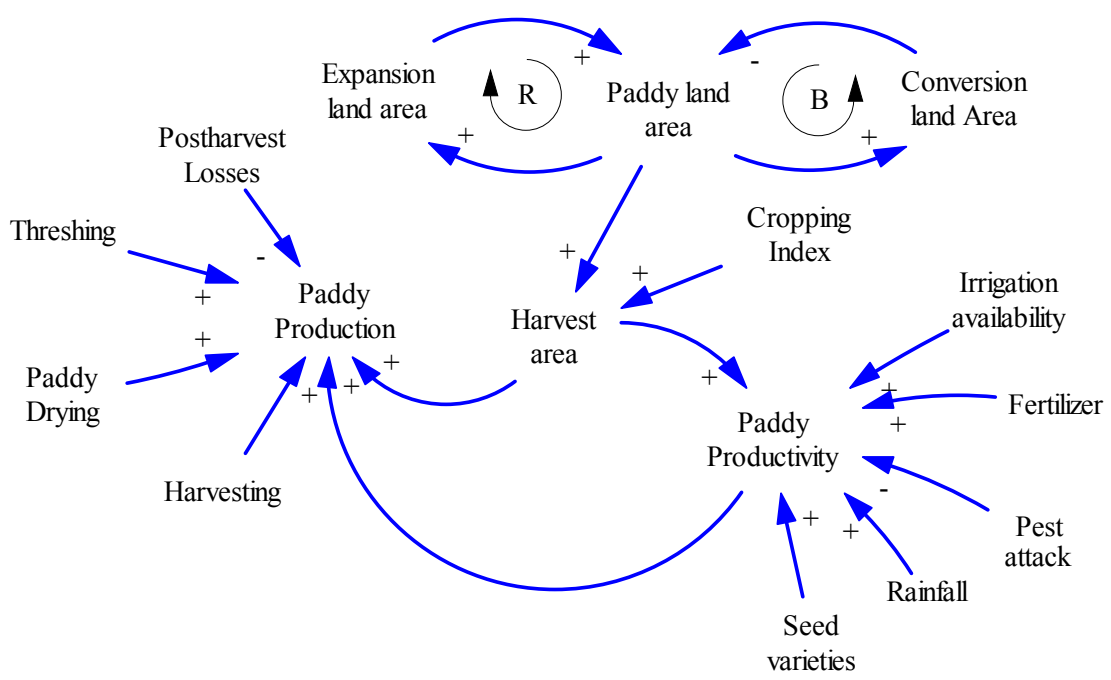

Fig.1 Causal loop diagram of paddy production

After the relationship between variables is obtained, the base model is developed as shown in Fig.2. Total paddy land area is the value of expansion land area minus the value of conversion land area. Total paddy production is the value of the harvested area multiplied by paddy productivity.

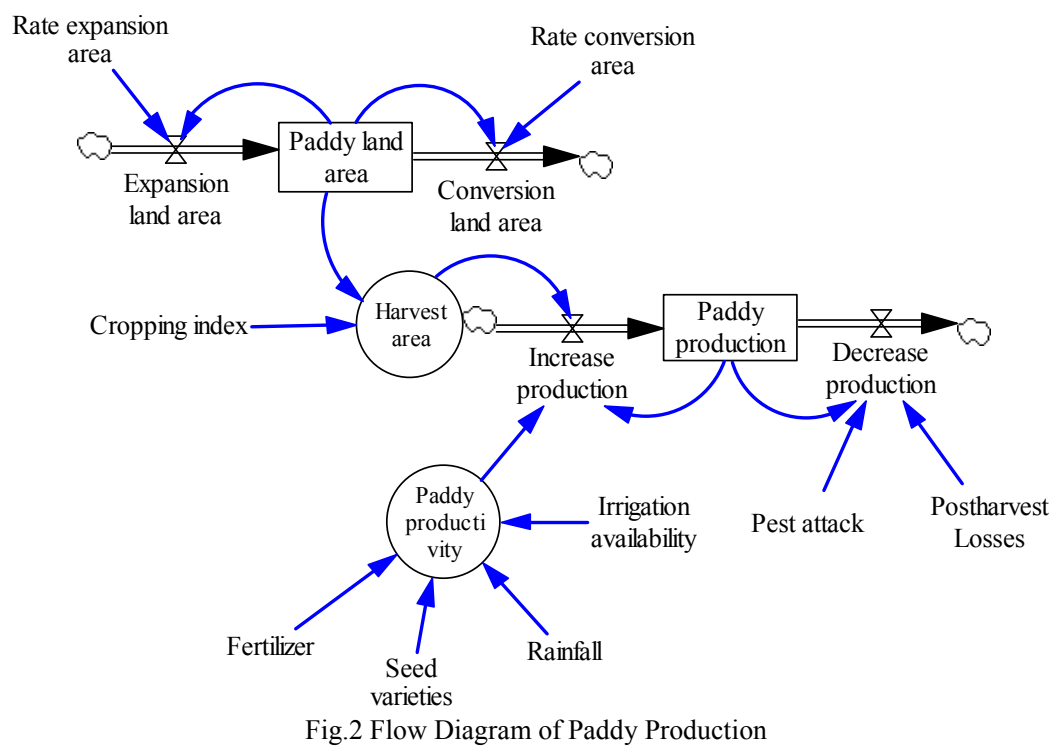

Model Validation is required to check the model accuracy. According to Barlas [34], a model will be valid if the error rate (E1) is less than or equal to $5 \%$ and the variance error (E2) is less than or equal to $30 \%$. The equation of error rate and error variance are shown in $(1)-(2)$.

$$
\begin{aligned}
& E 1=\frac{\mid(\text { Average rate of Data })-(\text { Average rate of Model }) \mid}{\text { Average rate of Data }} \\
& E 2=\frac{\mid(\text { Standart Deviation of Data })-(\text { Standart Deviation of Model }) \mid}{\text { Standart Deviation of Data }}
\end{aligned}
$$


The scenario development process is carried out to improve system performance. Model simulation is done to get the results and behaviour of the system during the simulation period. Simulation is done by entering input parameter values and changing the structure of the model if necessary [15]. In this study, the development of the scenario aims to increase rice production. The simulation period used for the model is from 2007 to 2025 . To obtain the goal of increasing paddy production, the following scenarios are carried out: (1) Scenarios for improving mechanism harvesting methods to increase paddy production; (2) Scenario increasing productivity with using good seed.

\section{RESULTS}

\section{A. Base Model Analysis}

In this section it will present the results of the rice production base model which is influenced by the area of harvested land, index of planting and rice productivity. In this study using a time span starting from 2007-2025 in million (M). The paddy production is show in Fig.3.

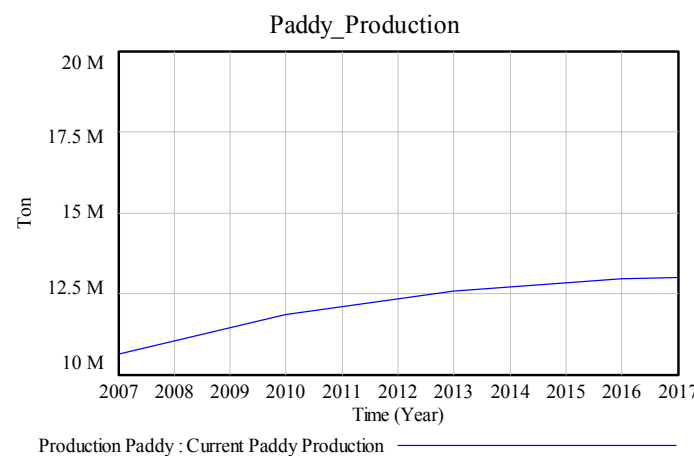

Fig.3 Result of paddy production simulation projection (Year: 2007-2025)

\section{B. Validation Output}

The validation model is required to check the model accuracy. According to Barlas [34], there are two ways of testing: Means Comparison (Error Rate) and Variations Comparison Amplitude (Error Variance). Here are the equations of the Error Rate (E1) and the Error Variance (E2). Here are the equations of the Error Rate (E1) and the Error Variance (E2). In this study the model was validated based on data that taken from the Agriculture Office of East Java [18]. The following is the result of the validation of the rice production base model can see in Tabel 4.

TABLE 4

MODEL VALIDATION

\begin{tabular}{lccc}
\hline \hline & Year & Data Production Paddy & Data Model Simulation \\
\hline 2007 & 10.836 .021 & 10.636 .021 \\
2008 & 10.474 .773 & 11.019 .456 \\
2009 & 11.259 .085 & 11.469 .045 \\
2010 & 11.643 .773 & 11.783 .351 \\
2011 & 10.576 .543 & 12.035 .969 \\
2012 & 12.198 .707 & 12.288 .484 \\
2013 & 12.049 .342 & 12.527 .876 \\
2014 & 12.397 .049 & 12.746 .277 \\
& 2015 & 13.154 .967 & 12.934 .489 \\
& 2016 & 13.633 .701 & 13.063 .137 \\
& 2017 & 13.125 .414 & 13.121 .270 \\
\hline Mean & 12.147 .761 & 11.940 .852 \\
\hline Standard Deviation & 842.108 & 1.036 .332 \\
\hline E1 & & & $2 \%$ \\
\hline E2
\end{tabular}

The following is a comparison chart of simulation results with original data for paddy productivity can be seen in Fig.4. From the results of the validation, it is known that E1 is less than 5\% with a value of $2 \%$ and E2 validation value is less than $30 \%$ with a value of $19 \%$, which means that the base model is valid. 


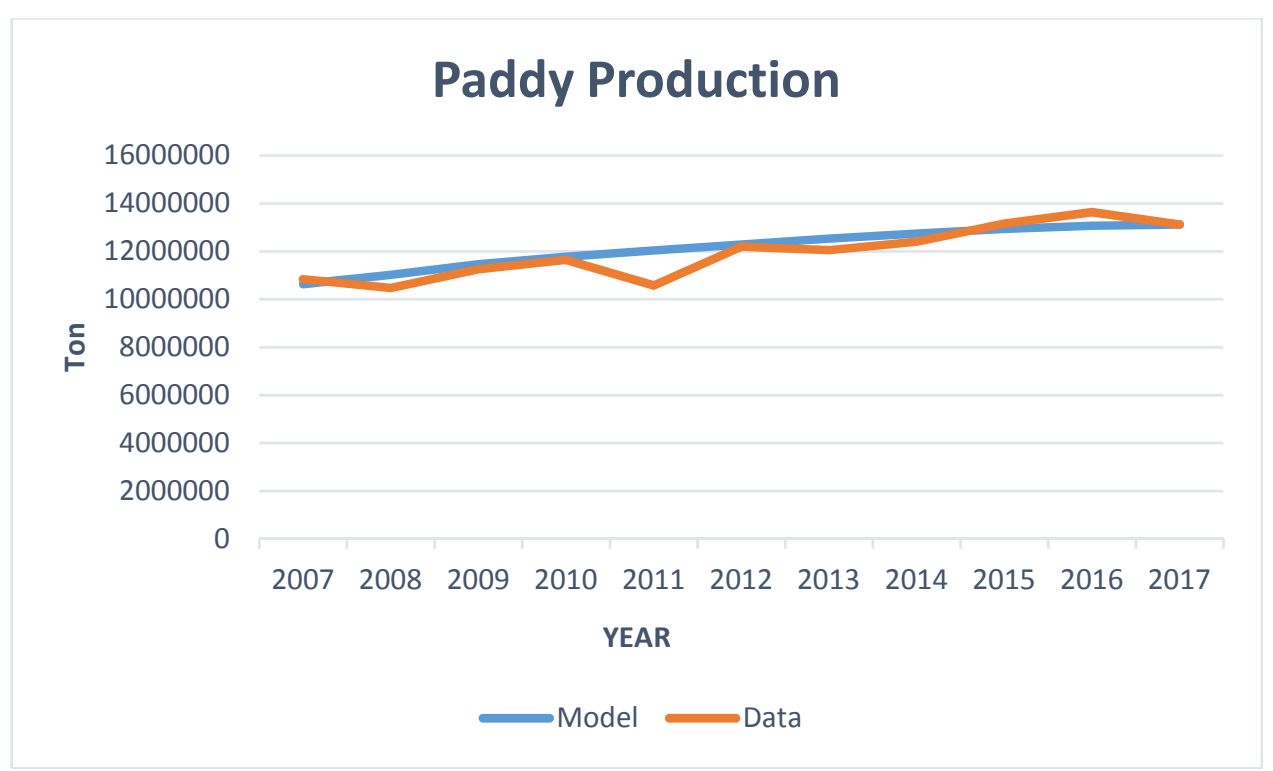

Fig.4 Model validation of paddy production

\section{Scenario Result}

According to BPS East Java data, harvesting activities of around 9.41\% were the cause of high yield losses in Indonesia and internationally, as stated by the International Rice Research Institute (IRRI) estimated that $5 \pm 16$ percent occurred during harvesting. According to the Buletin Tani [22] the causes of the rate of loss in the postharvest process are largely determined by rice varieties, local climate conditions and agricultural conditions in each country. In fact, the loss of rice yields is influenced by varieties, grain content during harvest, harvesting tools, methods of harvesting, threshing methods / tools, and rice harvesting systems since most farmers still use traditional methods or even though they have used mechanical equipment postharvest handling is still not good and right. Thus, the potential loss of yield occurs at every stage of rice post-harvest activity, namely the harvesting process, accumulation and collection, threshing, cleaning, transportation, drying, packaging and storage, and grinding. Loss of results when postharvest handlers start from threshing, drying, storing and grinding. The process of threshing rice provides a considerable contribution, which is equal to $4.42 \%$ in overall rice yield loss [22].

1) Scenario 1 Improve Agricultural Equipment and Machinery

This is very influential on the paddy production. The scenario 1 carried out was by repairing various agricultural equipment and machinery facilities. Improving the harvest mechanism by replacing traditional agricultural tools using modern agricultural tools coupled with the application of Good Agricultural Practice (GAP). This effort is expected to reduce the rate of yield loss during harvest and post-harvest in East Java and increase production of paddy. The result of scenario 1 improve agricultural equipemnt and machinery can be seen in Fig.5. in million (M).

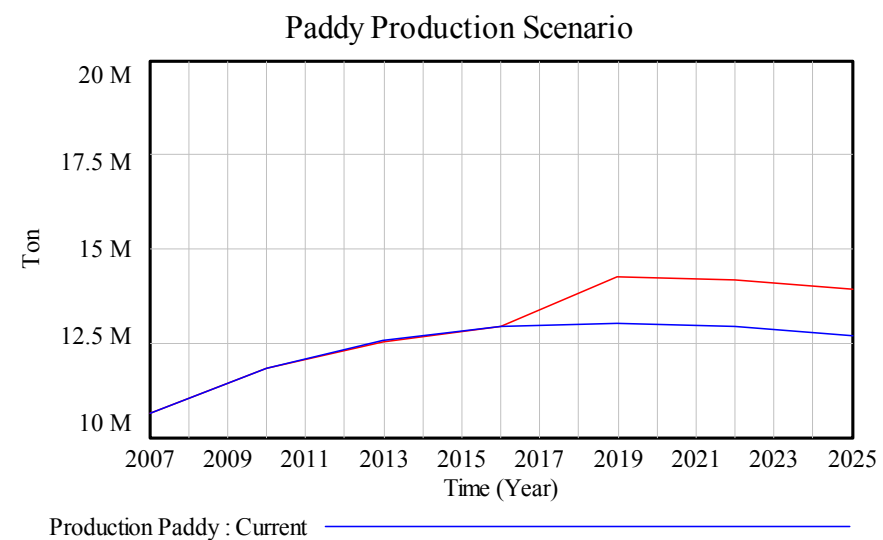

Production Paddy 0 : Scenario 1

Fig.5 Result Scenario 1 Improve Agricultural Equipment and Machinery 


\section{2) Scenario 2 Improve Seed Varieties}

Another factor that influences paddy production is paddy productivity. The average paddy productivity in East Java from 2007 - 2017 was 5.86 tons / ha. The average productivity is still below the land productivity in East Java in 2012 and 2015 which reached 6.1 tons / ha. So that the productivity of rice fields in East Java can be increased again. The scenario 2 of increasing productivity with using good seed is a parameter scenario. In this scenario the value of parameters that changed is "seed varieties" using superior seeds such will help increase paddy productivity. So that rice production also increases. The result of scenario 2 improve seed varieties can be seen in Fig.6. in million (M).

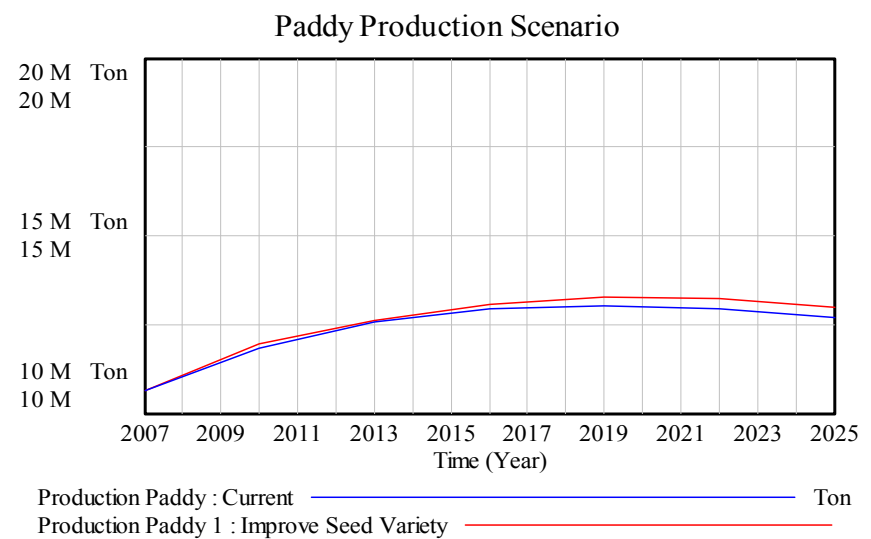

Fig.6 Result Scenario 2 Improve Seed Varieties

\section{DISCUSSION}

In a previous study conducted by Muslihudin [35], hefurther consider the handling of cultivation such as determining rice seeds that are suitable to be used in farming using the SAW (Simple Additive Weighting) method. The study was conducted by Wulandari [36] determining quality agricultural land to increase rice production by using the SAW (Simple Additive Weighting) method. Both of these studies focus on cultivation but do not consider the conditions of hervest and postharvest handling that can prevent crop losses and increase production yields. In this study try to include both conditions, namely harvest and post-harvest handling to increasing paddy production using the System Dynamics method. This method is very appropriate for complex dynamic and non-linear relationships. In addition, this method is based on the concept of feedback and multilinear non-loop. System dynamics method is suitable for understanding dynamic and complex agricultural systems which are carried out using traditional techniques.

The model simulation results show that rice area, harvest area, and paddy productivity affect rice production. To increase rice production to maintain food security, it was necessary to increase in several important parts. In increasing rice production, this study uses two scenarios, namely increasing productivity in the first scenario by using quality seeds [23] and improving the harvest mechanism by replacing traditional agricultural tools using modern agricultural tools coupled with the application of GAP [6].

Improper handling of crops and postharvest can cause a decrease in paddy production, causing huge losses for farmers. Harvesting paddy should use tools and machines that are suitable for the varieties to be harvested in accordance with Good Agricultural Practice (GAP) [37]. In addition post-harvest losses such as scattered rice which also causes low yields and low quality of grain / rice produced with high levels of impurities and empty grain and calcifying grains which results in low rendement of milled rice [22]. The drying process, which was done inappropriately, caused a decrease in the quality of the harvest and increased number of damaged paddies. The first scenario is an improvement in the harvest mechanism that is expected to help influence the yield of rice in East Java. The assumption in this scenario is to use a combination of tools according to Tjajoutomo [38] paddy mower use in the harvesting stage with a percentage loss of yield of $2 \%$, threshing stage using power thresher with a percentage shrinkage of $1.9 \%$, the drying stage with a flatbed dryer with a percentage shrinkage yield of 2.3\%. Good Agricultural Practice (GAP) such as the application of sensor optics to assess the nutritional status of plants, especially the nitrogen content based on chlorophyll content. The use of an optical sensor is used to measure the light reflection of the plant [39] so that it can estimate the amount of agricultural fertilizer with the right dose. The results of the simulation before the scenario in 2007 were 10,636,021 tons and in 2025 it was 12,693,416 tons. After scenario 1, rice production in 2007 was 10,636,021 tons and in 2025 it was $13,944,074$ tons shown in Figure 5. In this case rice production increased by 1,250,658 tons. 
The simulation results of paddy production in East Java with a land intensification scenario with the use of Inpari 43 Lanrang. The use of Inpari 43 superior seeds is able to provide potential yield of 9.02ton / ha. In addition, the use of these seeds in the generative phase is more resistant to attacks of leaf blight of pathotype III bacteria, pathotype IV, and pathotype VIII. The use of Inpari 43 is slightly susceptible to stem hopper and brown biotypes 1, 2 and 3 [40]. The use of superior seeds showed that paddy production before the scenario in 2007 was 10,636,021 tons and in 2025 it was 12,693,416 tons. After scenario 2, the paddy production in 2007 was $10,636,021$ tons and in 2025 it was 13,000,562 tons, in this case, paddy production increased by 307,146 tons. Based on these 2 scenarios a policy can be taken that the improvement of harvest mechanism by replacing traditional agricultural tools using modern agricultural tools coupled with the application of GAP is more significant in increasing rice production compared to improved rice productivity using superior seeds.

Food security largely depends on the amount of rice produced domestically. Our findings suggest that increasing paddy production can be done by improving the mechanism at the postharvest stage with the right techniques and tools for producing good quality harvest yield. Harvesting at the optimum age is very important to obtain the quality of paddy. Harvesting paddy must be done at the right age of harvest, using harvesting tools and machinery used to harvest rice must be in accordance with the type of paddy varieties to be harvested. The threshing is one of the postharvest stages which contributes significantly to the overall loss of yield. Drying is the process of decreasing grain moisture content until it reaches a certain value so that it is ready to be milled or safe to store for a long time. If the drying process is not controlled, the grain will be damaged.

In addition, the application of Good Agriculture Practice (GAP) such as the use of GPS (Global Positioning Systems) technology helps in mapping location, time, and monitoring in real time to control paddy cultivation. Recorded data such as planting status and attacking diseases can be monitored directly by the government, making it easier to provide recommendations for agricultural improvement. The application of several sensors and IoT to regulate soil management, fertilizer, and management of pest attack is very helpful in increasing rice production with good quality. Our findings suggest that subsidizing agricultural tools and the intensive importance of implementing harvesting mechanisms and implementing GAP are accompanied by technology to increasing production paddy with good quality.

\section{CONCLUSIONS}

The system dynamics model can provide insight for decision makers in improving food security through increasing rice production. In this article, rice production is influenced by harvest area, paddy productivity, and mechanism of harvest and post-harvest. Meanwhile, rice productivity depends on seed varieties, availability of irrigation, fertilization, and pest attacks. The simulation results are considered valid because they produce E1 values of $2 \%$ and $\mathrm{E} 2$ of $19 \%$. Based on the scenario that has been done with the improvement of the mechanism harvesting paddy, it will affect the increase in paddy production for the next 7 years. Further research is required to increase rendement rate of paddy.

\section{REFERENCES}

[1] D. P. Giraldo, M. J. Betancur dan S. Arango, "Food Security in Development Countries: A systemic perspective," Conference of the System, pp. 1-5, 2008.

[2] E. Suryani, R. A. Hendrawana, T. Mulyonoa dan L. P. Dewi, "System Dynamics Model to Support Rice Production and Distribution for Food Security," Jurnal Teknologi (Sciences \& Engineering), vol. 3, no. 68, pp. 45-51, 2014.

[3] T. Nurasa dan A. Purwoto, "Profitability Analysis on Irrigated Rice Farming in Java and the Outer Islands within the Patanas Rurality," Pusat Sosial Ekonomi dan Kebijakan Pertanian, pp. 405-424, 2011.

[4] A. Melkoyan, K. Krumme, T. Gruchmann dan G. D. L. Torre, "Sustainability assessment and climate change resilience in food production and supply," Energy Procedia, vol. 123, pp. 131-138, 2017.

[5] S. T. Lovell, "Multifunctional Urban Agriculture for Sustainable Land Use Planning in the United States," Sustainability, vol. 2, no. 8, pp. 2499-2522, 2010.

[6] A. S. Soemantri, P. Luna dan I. B. Jamal, "Strategy to increase rice production with the emphasis on the losses during harvest and postharvest using modeling system approach: Case study in district Indramayu, West Java," pp. 249-260, 2016.

[7] P. Karl M. Rich, M. Magda Rich dan M. Kanar Dizyee, "Participatory systems approaches for urban and peri-urban agriculture planning: The role of system dynamics and spatial group model building," Agricultural Systems j, vol. 160, pp. 110-123, 2018.

[8] A. Allen, "Environmental planning and management of the peri-urban interface: perspectives on an emerging field," Environmental Planning and Management, vol. 15, no. 1, pp. 135-148, 2003.

[9] J. Sterman, Business Dynamics: Systems Thinking and Modeling for a Complex World, 2000.

[10] B. Hannon dan B. McGarvey, Dynamic Modeling for Business Management: An Introduction, New York, 2004.

[11] A. D. Wibowoa, A. O. Moeis, C. B. Wiguna dan T. A. C. Chaulan, "Policy model of production and price of rice in Kalimantan Selatan," Agriculture and Agricultural Science Procedia, vol. 3, pp. 266-273, 2015.

[12] A. Chapman dan S. Darby, "Evaluating sustainable adaptation strategies for vulnerable mega-deltas using systemdynamics modelling: Rice agriculture in the MekongDelta's An Giang Province, Vietnam,” Science of the Total Environment, pp. 326-338, 2016. 
[13] B. K. Bala, M. G. K. Bhuiyan, M. M. Alam, F. M. Arshad, S. F. Sidique dan E. F. Alias, "Modelling of supply chain of rice in Bangladesh," International Journal of Systems Science: Operations \& Logistics, vol. 4, no. 2, pp. 181-197, 2017.

[14] R. Muetzelfeldt, "Extended System Dynamics modelling of the impacts of food system drivers on food security , livelihoods and the environment," 2010.

[15] N. Hasan, E. Suryani dan R. H. Department, "Analysis of Soybean Production And Demand to Develop Strategic Policy of Food Self Sufficiency: A System Dynamics Framework,” Procedia Computer Science, vol. 72, pp. 605-612, 2015.

[16] BPS, "Luas Lahan Sawah Irigasi dan Non Irigasi Menurut Kabupaten/Kota dan Jenis Pengairan di Provinsi Jawa Timur (Ha),” Badan Pusat Statistik Jawa Timur, Surabaya, 2017.

[17] BPS, "Produktivitas Padi Menurut Kabupaten/Kota di Jawa Timur,” Badan Pusat Statistik Jawa Timur, Surabya, 2018.

[18] D. P. J. Timur, "Laporan Kinerja (LKJ) 2014,” Dinas Pertanian Jawa Timur, 2015.

[19] S. Prabowo, "Pengolahan dan Pengaruhnya Terhadap Sifat Dan Kimia Serta Kualitas Beras," Jurnal Teknologi Pertanian, vol. 1, no. 2, pp. 43-49, 2006.

[20] R. Hasbullah dan R. Indaryani, "The Use of Threshing Technology to Reduce Grain Losses and Maintain Grain Quality of Paddy," Jurnal Keteknikan Pertanian, vol. 23, no. 2, pp. 111-118, 2009.

[21] D. K. S. Swastika, "The Role of Post Harvest Handling on Rice Quality in Indonesia," Forum Penelitian Agro Ekonomi, vol. 30, no. 1, pp. 1-11, 2012.

[22] B. Tani, "Upaya Meningkatkan Surplus Beras Jawa Timur dengan Menekan Kehilangan Hasil," Dinas Pertanian Provinsi Jawa Timur, Surabaya, 2016

[23] A. M. Stuart, K. P. Devkota, T. Sato, A. R. P. Pame, C. Balingbing, N. T. M. Phung, N. T. Kieu, P. T. M. Hieu, T. H. Long, S. Beebout dan G. R. Singleton, "On-farm assessment of different rice crop management practices in the Mekong Delta, Vietnam, using sustainability performance indicators," Field Crops Research, vol. 229, pp. 103-114, 2018.

[24] N. P. Banayo, S. M. Haefele, N. V. Desamero dan Y. Kato, "On-farm assessment of site-specific nutrient management for rainfed lowland rice in the Philippines," Field Crops Research, vol. 220, pp. 88-96, 2018.

[25] E. Berkhout, D. Glover dan A. Kuyvenhoven, "On-farm impact of the System of Rice Intensification (SRI): Evidence and knowledge gaps Ezra," Agricultural Systems journal, vol. 132, pp. 157-166, 2015.

[26] O. E. Olayide, I. K. Tetteh dan L. Popoola, "Differential impacts of rainfall and irrigation on agricultural production in Nigeria: Any lessons for climate-smart agriculture?," Agricultural Water Management journal, vol. 178, pp. 30-36, 2016.

[27] Z. Mohamed, R. Terano, J. Sharifuddin dan G. Rezai, "Determinants of Paddy Farmer's Unsustainability Farm Practices," Agriculture and Agricultural Science Procedia, vol. 9, pp. 191-196, 2016.

[28] X. Hong-xing, Y. Ya-jun, L. Yan-hui, Z. Xu-song, T. Jun-ce, L. Feng-xiang, F. Qian dan L. Zhong-xian, "Sustainable Management of Rice Insect Pests by Non-Chemical-Insecticide Technologies in China," Rice Science, vol. 24, no. 2, pp. 61-72, 2017.

[29] H. S. M. a. Z. A. Tanveer Ahmad, "EFFECT OF PADDY HARVESTING METHODS ON RICE QUALITY AND HEAD RICE RECOVERY," ARPN Journal of Engineering and Applied Sciences, vol. 11, no. 24, pp. 14519-14523, 2016.

[30] V. Milovanovic dan L. Smutka, "Cooperative rice farming within rural Bangladesh," Journal of Co-operative Organization and Management, vol. 6, no. 1, pp. 11-19, 2018.

[31] G. Mahajan, V. Kumar dan B. S. Chauhan, "Rice Production in India," dalam Rice Production Worldwide, 2017, pp. 53-93.

[32] M. Riaz, T. Ismail dan S. Akhtar, "Harvesting, Threshing, Processing, and Products of Rice," dalam Rice Production Worldwide, 2017, pp. 419-453.

[33] R. Hasbullah dan A. R. Dewi, "Kajian Pengaruh Konfigurasi Mesin Penggilingan Terhadap Rendemen Dan Susut Giling Beberapa Varietas Padi," Jurnal Keteknikan Pertanian, vol. 23, no. 2, pp. 119-124, 2009.

[34] Y. Barlas, "Formal aspects of model validity and validation in system dynamics," System Dynamics Review, vol. 12, pp. 183-210 , 1996.

[35] M. Muslihudin dan T. F. Abdillah, "Sistem Pendukung Keputusan Untuk Menentukan Kualitas Bibit Padi (Kasus Petani Podosari)," Jurnal TAM (Technology Acceptance Model), vol. 2, pp. 26-32, 2014

[36] Wulandari, A. Mustofa, Ponidi, M. Muslihudin dan F. A. Firdiansah, "Decision Support System Pemetaan Lahan Pertanian yang Berkualitas untuk Meningkatkan Hasil Produksi Padi Menggunakan Metode Simple Additive Wighting (SAW)," dalam Seminar Nasional Teknologi Informasi dan Multimedia, Yogyakarta, 2016.

[37] S. Saengabha, D. Jourdain, S. R. Perret dan G. Shivakoti, "Adoption and continued participation in a public Good Agricultural Practices program: The case of rice farmers in the Central Plains of Thailand," Technological Forecasting and Social Change, vol. 96, pp. 242-253, 2015.

[38] T. R, "Komersialisasi inovasi teknologi hasil petanian dan pengembangan pertanian,” Badan Penelitian dan Pengembangan Pertanian, Jakarta, 2008.

[39] J. D. Baerdemaeker, "Precision Agriculture Technology and Robotics for Good Agricultural Practices," dalam IFAC Proceedings Volumes (IFAC-PapersOnline), 2013.

[40] K. Pertanian, "https://www.litbang.pertanian.go.id/varietas/1207/". 